\title{
Comparative Study Of Rock Phosphate And Calcium Phosphate On The Growth \&Biochemistry Of Brassica Juncea And It's Impact On Soil Heath
}

\author{
Sandhya Buddh \\ Department Of Biotechnology Boston College For Professional Studies, Gwalior
}

\begin{abstract}
A study was conducted to compare the effect of rock phosphate \& calcium phosphate on the growth and the biochemistry of the plant Brassica juncea and its impact on soil health. The rock phosphate is highly favorable than tri-calcium phosphate for the mustard growth. Physiochemical effect of the plant was evaluated through the analysis of amino acid, pigment, shoot \& root biomass content of the plant. The following parameters of soil (treated with Tri calcium phosphate \& Rock phosphate) such as $\mathrm{pH}, \mathrm{EC}$, moisture, ash were analyzed. The $\mathrm{pH}$ of the soil mixed with tri-calcium phosphate and rock phosphate was decreased slightly from original \& EC was increased.Impact of rock phosphate \& calcium phosphate on the soil health can be observed by calculating TOC and nitrogen estimation at regular interval of days. Nitrogen concentration at 5th day is gradually decreases except control, $R 2$ and $R 4$ and after in 10th day and 20th day it becomes increased. The highest TOC value was observed on 10th day i.e. (C1)9.64 in calcium phosphate and R1 (10.17) on 1st day in rock phosphate.
\end{abstract}

\section{Introduction}

Phosphorus, one of the 17 chemical elements required for plant growth and reproduction, is often referred to as the "energizer" since it helps store and transfer energy during photosynthesis. It is also part of the genetic material of all cells-DNA and RNA.

All plants require phosphorus during periods of rapid growth. Most annual plants (plants that grow, reproduce and die in one year) require large amounts of phosphorus as they begin to grow. Plants grown in cold weather which have limited roots and rapid top growth, such as lettuce, are high phosphorus users. Legumes also require plentiful amounts of phosphorus. Established plants such as trees, shrubs and vines, especially those grown in warm climates with long summers, require the least amounts of phosphorus fertilizer.

In the soil, phosphorus is often found in chemical forms that cannot immediately be absorbed by plants, so farmers commonly apply phosphorus to the soil. The common source for commercial phosphorus fertilizer is rock phosphate,a calcium phosphate ore found in deposits within the earth. Rock phosphate is usually strip mined and then pulverized. The resulting material is treated with sulfuric, phosphoric or nitric acid to produce various soluble phosphates that can be used as fertilizers such as monoammonium phosphates diammonium phosphates and super-phosphates. Plants most often absorb phosphorus in the form of phosphate ions $\mathrm{H}_{2} \mathrm{PO}_{4}^{-}$ and sometimes as $\mathrm{HPO}^{2-}$. These phosphate ions react readily with the soil and become part of the soil particles in a process called "fixation." Fixation prevents the leaching of phosphorus, but also changes it to a form that plants cannot use. The challenge in agriculture is to provide plants with the proper amount of phosphorus, in the proper form, at time when the roots will absorb it.

Phosphorus is very mobile in plants; relatively immobile in soil and does not leach. It is stored in seeds and fruit. It is most readily available to plants between a pH of 6 and 7.5 (unavailable in very acid or alkaline soils). Found in greatest concentration in sites of new cell growth. Phosphorus absorption is reduced at low soil temperatures. Phosphorus is necessary to stimulate early root formation and growth, hasten crop maturity, stimulate flowering and seed production, give winter hardiness to fall plantings and seeding, and promote vigorous start (cell division) to plants. Phosphorus has a role in fat, carbon, hydrogen, and oxygen metabolism, in respiration, and in photosynthesis.

\section{P Deficiency symptoms}

- Red or purplish color (anthocyanin pigment) in leaves, especially undersides.

- Death of tissue or necrosis may follow and root growth is poor.

- Lower stems may be purplish. Plants may exhibit stunting and delayed maturity.

- Loss of water from lower leaves and it may exhibit reduced flowering. 


\section{Sources of phosphorous}

- Organic: bone meal, animal manures

- Inorganic (rock powders): colloidal phosphate, rock phosphate

Phosphorus is vital to the growth and health of plants. It assists in converting the sun's energy and other chemicals, such as nitrogen, into usable food for plants. It (P) enables a plant to store and transfer energy, promotes root, flower and fruit development, and allows early maturity. A phosphorus deficiency will lead to stunted, sickly looking plants that produce a lower quality fruit or flower. Soil naturally contains phosphorus, but due to today's high-yielding crops and landscaping plants, more phosphorus is required to attain the desired effect, so adding phosphorous. There are two types of phosphorus available: organic and inorganic.

\section{Inorganic phosphorus}

The main inorganic forms of phosphorus in soil are $\mathrm{H}_{2} \mathrm{PO}_{4}{ }^{-}$and $\mathrm{HPO}_{4}{ }^{2-}$. This is the form in which Phosphorous is used by plants. However, these ions can also absorb onto the surface (or adsorb into) solid matter in the soil. This phosphorus is then unavailable to plants.

\section{Organic phosphorus}

Between 50 and $80 \%$ of phosphorus in soil is organic phosphorus. This comes from the breakdown of dead plants etc., as phosphorus is found in cell membranes and DNA in living organisms.

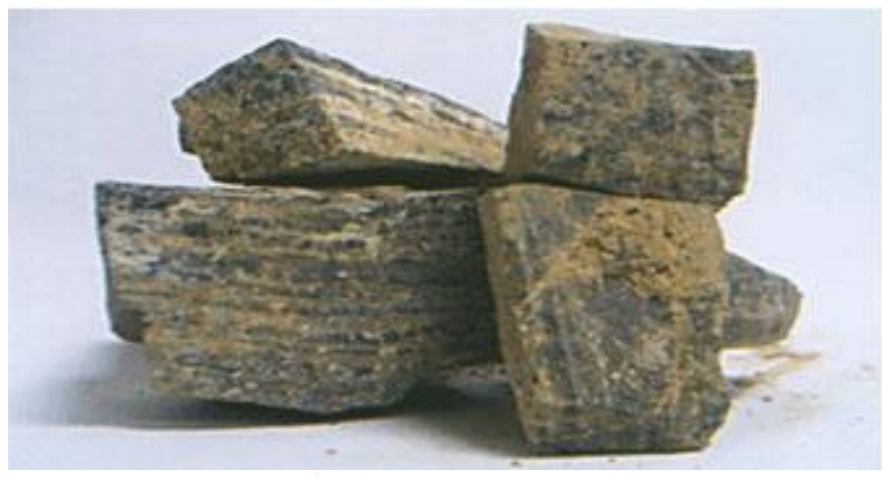

Fig-1 Rock phosphate

Rock phosphate, Phosphorite, phosphate rock or is a non-detrital sedimentary rock which contains high amounts of phosphate bearing minerals. The phosphate content of phosphorite is at least 15 to $20 \%$, which is a large enrichment over the typical sedimentary rock content of less than $0.2 \%$. The phosphate is present as fluorapatite $\mathrm{Ca}_{5}\left(\mathrm{PO}_{4}\right)_{3} \mathrm{~F}$ (CFA) typically in cryptocrystalline masses. Rock phosphate is another mineral used in the manufacture of phosphatic fertilizers. On agriculture, the fertilizer production plays a pivotal role. Only about $35 \%$ to $40 \%$ of the requirements of raw material for phosphatic fertilizer production are being met through indigenous sources and the rest is met through import in the form of rock phosphate, phosphoric acid \& direct fertilizers.

Phosphatic minerals are insoluble in water. Hence, these are treated with sulfuric acid to prepare superphosphate which is easily dissolved in water and applied to the soil.

Occurrence of Rock Phosphate

The main occurrence of rock phosphate in India on a workable scale are : lime phosphate septarian nodules in clay beds associated with the Cretaceous rocks. Rajasthan-Rajasthan is the largest producer accounting for 93.9 per cent of the total production of rock phosphate in the country.

Benefits of Rock Phosphate for plants

- Essential for seed production.

- Promotes increased root growth.

- Promotes early plant maturity (less time for grain ripening).

- Promotes stalk strength.

- Promotes resistance to root or shoot diseases.

- Promotes resistance to winter kill.

Rock phosphates are applied as a fine powder that is thoroughly mixed through the soil. This enhances the continued dissolution of the rock phosphate. Plant roots are more likely to intercept the phosphorus dissolved from rock phosphate particles that are dispersed widely through the soil so increasing the proportion of the dissolved water soluble phosphorus taken up by plants than is adsorbed by soil. 
In addition to the importance of $\mathrm{P}$ in plant functions, the agronomic literature is full of examples of grain, fiber and forage yield increases due to proper maintenance of P fertility. Clearly, P is a necessary and beneficial input for modern crop production systems.

\section{Tri-calcium phosphate}

Tri-calcium phosphate is a calcium salt of phosphoric acid with the chemical formula $\mathrm{Ca}_{3}\left(\mathrm{PO}_{4}\right)_{2}$. It is also known as tribasic calcium phosphate. Calcium phosphate being one of the main combustion products of bone, see bone ash. It has an alpha and a beta crystal form, the alpha state being formed at high temperatures. As rock, it is found in Whitlockite. The name calcium phosphate refers to minerals containing calcium ions $\left(\mathrm{Ca}^{2+}\right)$ together with orthophosphates $\left(\mathrm{PO}_{4}{ }^{3-}\right)$,metaphosphates or pyrophosphates $\left(\mathrm{P}_{2} \mathrm{O}_{7}{ }^{4-}\right)$ and occasionally hydrogen or hydroxide ions. Especially, the common mineral apatite has formula $\mathrm{Ca}_{5}\left(\mathrm{PO}_{4}\right)_{3} \mathrm{X}$, where $\mathrm{X}$ is $\mathrm{F}, \mathrm{Cl}, \mathrm{OH}$, or a mixture; it is hydroxyapatite if the extra ion is mainly hydroxide. Much of the "tricalcium phosphate" on the market is actually powdered hydroxyapatite.

\section{Occurrence}

It is found in nature as a rock in Morocco, Israel, Philippines, Egypt, and Kola (Russia) and in smaller quantities in some other countries. The natural form is not completely pure, and there are some other components like sand and lime which can change the composition. In terms of $\mathrm{P}_{2} \mathrm{O}_{5}$, most calcium phosphate rocks have a content of $30 \%$ to $40 \% \mathrm{P}_{2} \mathrm{O}_{5}$ in weight.

\section{Root morphology and shoot morphology affected by $p$ availability}

Plants growing in P-deficient soil allocate a greater proportion of assimilates to root growth and tend to have fine roots of a small diameter and therefore a large surface area. P-efficient barley (Gahoonia et al., 2001) and cowpea cultivars (Krasilnikoff et al., 2003) have longer root hairs allowing them to take up more P in comparison with P-inefficient genotypes. P-deficient Lupinus angustifolius increased the primary root elongation and developed a large number of the cluster-like first-order lateral roots with dense root hairs, thus allowing efficient $\mathrm{P}$ acquisition under low P supply (Wang et al., 2008). Fine roots and especially root hairs effectively scavenge $\mathrm{P}$ from soils because of a large surface area of contact with the soil.

The shoot $\mathrm{P}$ status may regulate the formation of cluster roots, as specialized structures of selected plant species for thorough exploration of the soil volume (Lambers et al., 2006; Shu et al., 2007b). However, the form of P in soils may also regulate cluster root formation (Shu et al., 2007a; Shu et al., 2007b). In addition, the development of cluster roots can respond to a presence of organic matter adjacent to the root (Adams and Pate 1992).

\section{Exudation of organic compounds through plant}

Under P deficiency, plants exude a wide range of organic compounds (carboxylates, enzymes, phenolics, etc.) to increase mobilization of P from sparingly soluble sources (eg. Neumann and Römheld, 1999). Typical carboxylates (organic acid anions) found in root exudates of P-deficient plants include citrate, malate, malonate, acetate, fumarate, succinate, lactate and oxalate (see Rengel, 2002). In barley, P-use efficiency may be linked to the capacity of genotypes to increase exudation of citrate as an organic acid anion with a strong capacity to mobilise P (Gahoonia et al., 2000).

\section{Soil microorganisms involve in phosphorus mobilization}

A considerable number of bacterial species are able to exert a beneficial effect upon plant growth. Mostly they are associated with the plant rhizosphere, so they are called as rhizobacteria. This group of bacteria has been termed plant growth promoting rhizobacteria, and among them are strains from genera such as Alcaligenes, Acinetobacter, Arthrobacter, Azospirillum, Bacillus, Burkholderia, Enterobacter, Erwinia, Flavobacterium, Paenibacillus, Pseudomonas, Rhizobium, and Serratia. They are used as biofertilizers or control agents for agriculture improvement, and there are numerous researchers for the area with the agricultural environment conservation.

\section{Effect of soil microorganism in Phosphorus mobilization}

Microorganisms directly affect the ability of plants to acquire $\mathrm{P}$ from soil through a number of structural or process-mediated mechanisms. These include (i) an increase in the surface area of roots by either an extension of existing root systems (eg, mycorrhizal associations) or by enhancement of root branching and root hair development (ie, growth stimulation through phytohormones), (ii) by displacement of sorption equilibria that results in increased net transfer of phosphate ions into soil solution or an increase in the mobility of organic forms of $\mathrm{P}$ and (iii) through stimulation of metabolic processes that are effective in directly 
solubilizing and mineralizing $\mathrm{P}$ from poorly available forms of inorganic and organic $\mathrm{P}$. These processes include the excretion of hydrogen ions, the release of organic acids, the production of siderophores and the production of phosphatase enzymes that are able to hydrolyse soil organic P. In particular, organic acids and associated protons are effective in solubilizing precipitated forms of soil $\mathrm{P}$ (eg, Fe- and Al-P in acid soils, Ca-P in alkaline soils), chelating metal ions that may be associated with complexed forms of $\mathrm{P}$ or may facilitate the release of adsorbed P through ligand exchange reactions (Jones, 1998).

\section{Review Of Literature}

Phosphorous management based on soils, climate and other agronomic factors.

Mullins and Hajek, 1996, studying soils receiving poultry litter found when P adsorption was related to clay content, adsorption and desorption was essentially the same per unit of clay for soils with kaolinitic mineralogy. Their study suggested that as a critical level of $300 \mathrm{mg} / \mathrm{kg}$ is approached, management measures should be taken to limit further P buildup. It was also shown that 20 year simulations with the EPIC model compared favorably with data from an earlier study (Kingery, et al. 1994). The use of models such as EPIC could provide an evaluation of proposed and recommended practices for P management based on real onsite climate, soils, and other agronomic factors.

\section{Effect of Rock phosphate in alkaline soils.}

Elliott \& Christensen et.al in 2012 has studied for P availability in alkaline soils, rock phosphate provided no soil $\mathrm{P}$ concentration differences or yield improvements over the control after two growing seasons. Therefore, rock $\mathrm{P}$ was not effective in providing plant available $\mathrm{P}$ in high $\mathrm{pH}$ soils. On alkaline soils, research shows that it is best to use composted or vermicomposted manure to minimize environmental impacts. However, raw manure also proves to be a beneficial and provides plant available $P$.

\section{Use of low- grade rock phosphate in the removal of lead, copper, zinc and cobalt ions.}

The low- grade rock phosphate of Jhabua, Madhya Pradesh (India), was investigated for its possible application in the removal of lead, copper, zinc and cobalt ions from aqueous solutions. Effects of contact time, amount of adsorbent and initial concentration of metal ions were studied. Adsorption of heavy metal ions was found to follow the order: $\mathrm{Pb}^{2+}>\mathrm{Cu}^{2+}>\mathrm{Zn}^{2+}>\mathrm{Co}^{2}$. The probable mechanism of metal ions removal by rock phosphate was found to be by its dissolutions followed by subsequent precipitation studied by SonaSaxena and S.F. D'Souza.

Effects of Phosphorus Nutrition on Ribulose-1,5-Bisphosphate Carboxylase Activation, Photosynthetic Quantum Yield and Amounts of Some Calvin-Cycle Metabolites in Spinach Leaves

When spinach plants were transferred to nutrient solutions without phosphorus, the photosynthetic rate per unit leaf area gradually declined. Stomatal conductance also decreased but was not the sole cause of the decreased photosynthetic rate because the partial pressure of $\mathrm{CO}_{2}$ in the intercellular spaces $\left(\mathrm{C}_{\mathrm{I}}\right)$ was unaltered. Measurements of the photosynthetic rate as a function of $\mathrm{C}_{\mathrm{I}}$ indicated reductions in both ribulose bisphosphate $\left(\mathrm{RuP}_{2}\right)$ carboxylase activity and $\mathrm{RuP}_{2}$ regeneration capacity. From assays of $\mathrm{RuP}_{2}$ carboxylase activity in vitro and 'percentage activation', it was concluded that low-P leaves had less enzyme per unit area than controls and that the enzyme was also less activated. The photosynthetic quantum yield was reduced by phosphorus deficiency with no effect on leaf absorptance or chlorophyll content. The reduced quantum yield was accompanied by changes in chlorophyll fluorescence of photosystems I and II measured at 77K. However, since phosphorus deficiency did not affect the uncoupled rate of whole-chain electron transport in vitro, some factor(s) other than photo inhibition probably contributed to the reduced quantum yield. The lack of effect on this electron-transport rate also indicates that the maximal $\mathrm{RuP}_{2}$ regeneration rate in low-P leaves was not limited by the amount of electron -transport components. At ambient $\left[\mathrm{CO}_{2}\right]$, low-P leaves had significantly less $\mathrm{RuP}_{2}$ and 3-phosphoglycerate (PGA) than controls and the response of photosynthesis to low $\left[\mathrm{O}_{2}\right]$ was similar to control leaves. Therefore photosynthesis did not appear to be limited by triose-phosphate utilization. The low concentrations of $\mathrm{RuP}_{2}$ and PGA (and presumably other Calvin-cycle intermediates) might have reduced the rate of the Calvin cycle. After returning low-P plants to nutrient solutions with $\mathrm{PO}_{4}$, the percentage activation of $\mathrm{RuP}_{2}$ carboxylase, amounts of $\mathrm{RuP}_{2}$ and $\mathrm{PGA}$, quantum yield and maximal $\mathrm{RuP}_{2}$ regeneration rate increased within $24 \mathrm{~h}$. The quantum yield and photosynthetic rate at higher irradiance also increased when leaf discs from low-P plants were floated on $10 \mathrm{mM} \mathrm{PO}_{4}$ solutions for $2 \mathrm{~h}$.

\section{Phosphorus solubilizing bacteria role in phosphorus nutrition.}

Plants acquire phosphorus from soil solution as phosphate anion. It is the least mobile element in plant and soil contrary to other macronutrients. It precipitates in soil as orthophosphate or is absorbed by $\mathrm{Fe}$ and $\mathrm{Al}$ oxides through legend exchange. Phosphorus solubilizing bacteria play role in phosphorus nutrition by enhancing its availability to plants through release from inorganic and organic soil P pools by solubilization and 
mineralization. Principal mechanism in soil for mineral phosphate solubilization is lowering of soil $\mathrm{pH}$ by microbial production of organic acids and mineralization of organic $\mathrm{P}$ by acid Phosphatase. Use of phosphorus solubilizing bacteria as inoculants increases $\mathrm{P}$ uptake. These bacteria also increase prospects of using phosphatic rocks in crop production. Greater efficiency of P solubilizing bacteria has been shown through co-inoculation with other beneficial bacteria and mycorrhiza. This article incorporates the recent developments on microbial $\mathrm{P}$ solubilization into classical knowledge on the subject was given by Sonam Sharma et al.(2011).

\section{All microbes help in the uptake of tricalcium phosphate by the plants.}

The interactive effects of phosphate solubilizing bacteria, N2 fixing bacteria and arbuscularmycorrhizal fungi (AMF) were studied in a low phosphate alkaline soil amended with tricalcium insoluble source of inorganic phosphate on the growth of an aromatic grass palmarosa (Cymbopogonmartinii). The microbial inocula consisted of the AM fungus Glomusaggregatum, phosphate solubilizing rhizobacteria Bacillus polymyxa and N2 fixing bacteria Azospirillumbrasilense. These rhizobacteria behaved as "mycorrhiza helper" and enhanced root colonization by G. aggregatum in presence of tricalcium phosphate at the rate of $200 \mathrm{mg} \mathrm{kg}(-$ 1) soil ( $\mathrm{P} 1$ level). Dual inoculation of G. aggregatum and B. polymyxa yielded $21.5 \mathrm{~g}$ plant dry weight (biomass), while it was $21.7 \mathrm{~g}$ in B. polymyxa and A. brasilense inoculated plants as compared to $14.9 \mathrm{~g}$ of control at the same level. Phosphate content was maximum (0.167\%) in the combined treatment of G. aggregatum, B. polymyxa and A. brasilense at P1 level, however acid phosphatase activity was recorded to be 4.75 pmolmg(-1) $\min (-1)$ in G. aggregatum, B. polymyxa and A. brasilense treatment at P0 level. This study indicates that all microbes inoculated together help in the uptake of tricalcium phosphate which is otherwise not used by the plants and their addition at $200 \mathrm{mg} \mathrm{kg}(-1)$ of soil gave higher productivity to palmarosa plants was reported by Ratti N, Kumar S, Verma HN, Gautam SP (2001).

\section{Phosphate solubilizing microorganisms increases efficiency of rock phosphate as fertilizers.}

Hossein, Khayami, Besharati et al.(2010) was reported rock phosphate is the source of chemical phosphorus fertilizers but its solubility is very low and one of the solutions for increasing its efficiency is application of phosphate solubilizing microorganisms. A greenhouse experiment was performed with Bacillus subtilis and Pseudomonas putida, five levels of rock phosphate $(0,25,50,75$ and 100 percent of the difference to an optimum level of $16 \mathrm{ppm}$ ), in three soils with different amounts of available P (Low, Medium and High) in four replications. Their effects on single plant dry matter of corn and plant $\mathrm{P}$ uptake was determined using standard analytical methods. Results showed that pseudomonas, with maximum fertilizer treatments and soil with medium P had highest dry matter. Treatments without bacteria had highest P uptake, one of the reasons could be excretion of deleterious materials by bacteria. Fertilizer levels were not significantly different from each other. Perhaps it is because of the small differences between selected levels. In addition, applied rock phosphate had low solubility in these soils $(\mathrm{pH}=7.5-8)$, even under the effects of phosphate solubilizing bacteria.

\section{PR was effective in increasing arsenic uptake and decreasing metal uptake by $P$.}

Ma et al. (2005) studied on the greenhouse experiment evaluated the effects of phosphate rock (PR) on arsenic and metal uptake by the arsenic hyper accumulator Pterisvittata in a soil spiked with arsenic and heavy metals $\mathrm{Cd}, \mathrm{Pb}$ and $\mathrm{Zn}$.. The plants were harvested after growing in the soil for five weeks. Compared to the As treatment, the presence of heavy metals (AsM) reduced arsenic concentrations in the fronds from 1631 to 608 $\mathrm{mg} \mathrm{kg} 1$. However, this effect was mitigated by PR (AsMP), with arsenic concentrations in the fronds increased from 608 to $1046 \mathrm{mg} \mathrm{kg}{ }^{-1}$. Phosphate rock also significantly reduced $\mathrm{Pb}$ (13.5 to $\left.4.10 \mathrm{mg} \mathrm{kg} \_1\right)$ and $\mathrm{Cd}$ (13.0 to $3.45 \mathrm{mg} \mathrm{kg}{ }^{-1}$ ) concentrations in the fronds. Most of the arsenic in P. vittata was accumulated in the fronds (8993\%). Compared to the control, $\mathrm{P}$ was more concentrated in the roots along with less $\mathrm{P}$ being translocated to the fronds in the treatments with arsenic. While in those same treatments higher $\mathrm{Ca}$ concentrations in both the fronds and roots were observed. This research shows that PR was effective in increasing arsenic uptake and decreasing metal uptake by P. vittata and thus can be used as a cost-effective amendment for phytoremediation of arsenic and metal polluted soils.

\section{Modifications of photosynthetic metabolism observed under moderate phosphate deficiency.}

Kondracka and Rychter et al.(1997) was reported on bean plants \{Phaseolus vulgaris L. cv. ZlotaSaxa) that were grown on complete (control plants) and phosphate-deficient (low-P plants) culture solutions for $17 \mathrm{~d}$. Phosphate deficiency markedly reduced leaf growth, but only slightly decreased the photosynthesis rate. The intensity of reactions releasing inorganic orthophosphate during photosynthesis was examined. In the leaves of low-P plants the pools of photo respiratory metabolites (glycolate and glycine + serine) were markedly increased. At the same time synthesis of soluble sugars from intermediates of glycolic acid cycle was probably enhanced. In low-P leaves the phosphoenolpyruvate carboxylase activity and malate synthesis were increased. 
Phosphoenolpyruvate and malate were effectively used for amino acid synthesis. Both aspartate and alanine accumulation was twice higher in low-P leaves. It was found that no enhancement in starch and sucrose synthesis rate takes place in phosphate deficient bean leaves. Modifications of photosynthetic metabolism observed under moderate phosphate deficiency facilitate plants acclimation to low-P conditions by enhancement of $\mathrm{P}$, recirculation during glycolic and phosphoenolpyruvate metabolism.

\section{Different strategies by which plants and microorganisms may improve P-use efficiency.}

Scope(2011) Three strategies by which plants and microorganisms may improve P-use efficiency are outlined: (i) Root-foraging strategies that improve $\mathrm{P}$ acquisition by lowering the critical $\mathrm{P}$ requirement of plant growth and allowing agriculture to operate at lower levels of soil P; (ii) P-mining strategies to enhance the desorption, solubilization or mineralization of $\mathrm{P}$ from sparingly-available sources in soil using root exudates (organic anions, phosphatases), and (iii) improving internal P-utilization efficiency through the use of plants that yield more per unit of $\mathrm{P}$ uptake.

Rengel (2008) was reported onan increasing need to produce food for the expanding world population creates significant pressure on suitable land already in production and requires continuous expansion of foodproducing ecosystems into less fertile areas. In every such food-producing system, crops and pastures must be provided with sufficient nutrients for vigorous growth and high outputs, putting an emphasis on understanding soil-plant microbe interactions governing nutrient acquisition by plants. This review will summarize the available knowledge on relevant interactions underlying plant acquisition of $\mathrm{P}$ and micronutrients (with an emphasis on Mn)

\subsection{Collection of soil sample}

\section{Material And Methods}

Soil samples were collected from garden of radiation lab (CIMFRcampus) which requires predetermination of sampling depth, position relative to nutrient application patterns, and sampling intensity within the field. The factors which are considered when determining the appropriate sampling depth: 1) influence of changes in soil morphology with depth (i.e., horizonation); 2) influence of surface soil management (e.g., tillage); and 3) necessity to maintain sample collection depth uniformity across numerous sites.

\subsection{Sample Handling, and Preparation and Storage}

Air dried and crushed soil samples are stable at room temperature. The samples were then air-dried, powered and passed with $2 \mathrm{~mm}$ sieve. Then the each $200 \mathrm{~g}$ of soil was mixed with different concentration of rock phosphate and calcium phosphate as given in Set: $1 \&$ Set: 2 and taken for the study.

Experiment design by the use of rock phosphate and tri-calcium phosphate.

Table1: Experimental design using rock phosphate

\begin{tabular}{|c|c|}
\hline S1. No. & Concentration of RP \\
\hline R1 & $0.2 \mathrm{~g}$ \\
\hline R2 & $0.4 \mathrm{~g}$ \\
\hline R3 & $0.6 \mathrm{~g}$ \\
\hline R4 & $0.8 \mathrm{~g}$ \\
\hline RN & Nil \\
\hline
\end{tabular}

*RP=Rock phosphate

Table2: Experimental design using tri-calcium phosphate

\begin{tabular}{|c|c|}
\hline S1. No. & Concentration of CP \\
\hline C1 & $0.2 \mathrm{~g}$ \\
\hline $\mathrm{C} 2$ & $0.4 \mathrm{~g}$ \\
\hline $\mathrm{C} 3$ & $0.6 \mathrm{~g}$ \\
\hline $\mathrm{C} 4$ & $0.8 \mathrm{~g}$ \\
\hline $\mathrm{CN}$ & $\mathrm{Nil}$ \\
\hline
\end{tabular}

${ }^{*} \mathrm{CP}=$ Calcium Phosphate

\subsection{Analysis of Physiochemical parameters of soil sample:}

\subsection{1 $\mathrm{P}^{\mathrm{H}}$ analysis of soil samples}

$\mathrm{P}^{\mathrm{H}}$ is negative logarithm of $\mathrm{H}^{+}$ions and in acidic soils; $\mathrm{P}$ is fixed in either $\mathrm{Al}$ or $\mathrm{Fe}$ complexes, whereas in calcareous soils of higher $\mathrm{pH}$ it is Ca phosphate complexes. $\mathrm{P}^{\mathrm{H}}$ analysis of soil sample is obtained by $10 \mathrm{gm}$ of $2 \mathrm{~mm}$ passed soil in $25 \mathrm{ml}$ distilled water and then stirs it for 15 minutes and then $\mathrm{P}^{\mathrm{H}}$ was measured by $\mathrm{P}^{\mathrm{H}}$ meter.

\subsubsection{EC analysis of soil samples}


Estimation Electrical conductivity of soil sample is obtained by $10 \mathrm{gm}$ of $2 \mathrm{~mm}$ passed soil in $25 \mathrm{ml}$ distilled water and then stirs it for 15minutes and then EC was measured.

\subsubsection{Moisture analysis}

Moisture analysis is the determination of the amount of water in a substance usually; moisture analysis is reported as a percent of moisture on a weight basis. The method of measuring level of moisture in solid or semi-solid materials is loss on drying (LOD). In this technique a $1 \mathrm{~g}$ of sample of material is weighed, heated in an oven for an hour and then cooled in the dry atmosphere of desiccators, and then reweighed. If the volatile content of the solid is primarily water, the LOD technique gives a good measure of moisture content. The loss in weight before and after the heating is taken as moisture.

\section{Calculations:}

Moisture content $=$ initial weight - final weight

Initial weight $=$ Weight of crucible + Sample (Before heating)

Final weight $=$ Weight of crucible + Sample (After heating)

\subsubsection{Ash analysis}

Ash is obtained by complete combustion of inorganic mineral matter of sample.1gm powdered sample taken in silica dish heated in muffle furnace in which temperature is raised to $800^{\circ} \mathrm{C}$ for $45-60$ minutes. The loss in weight before and after heating is taken as ash content.

\section{Calculations:}

Moisture content $=$ initial weight - final weight

Initial weight $=$ Weight of crucible + Sample (Before heating)

Final weight $=$ Weight of crucible + Sample (After heating)

\subsection{Analysis of biochemical properties of soil sample}

3.4.1 Estimation of Total Organic Carbon (TOC) by Walkley- Black method (Nelson and Sommers, 1982).

\section{Reagents for soil organic carbon estimation}

$\mathrm{K}_{2} \mathrm{Cr}_{2} \mathrm{O}_{7}(1 \mathrm{~N}) 10 \mathrm{ml}$ : $49 \mathrm{gm}$ potassium dichromate in $1000 \mathrm{ml}$ distilled water, ferrous ammonium sulfate (FAS) as titrant, concentrated $\mathrm{H}_{2} \mathrm{SO}_{4} 20 \mathrm{ml}$, orthophosphoric acid $10 \mathrm{ml}$, diphenylamine (DPA) as indicator 2-10 drops.

\section{Procedure for soil organic carbon estimation}

$10 \mathrm{ml} \mathrm{K} \mathrm{K}_{2} \mathrm{Cr}_{2} \mathrm{O}_{7}$ added to $0.1 \mathrm{gm}$ sample then after added $20 \mathrm{ml}$ concentrated $\mathrm{H}_{2} \mathrm{SO}_{4}$ with continuous stirring and left for digestion. After 30 minutes $200 \mathrm{ml}$ distilled water and $10 \mathrm{ml}$ orthophosphoric acid added to the flask after that 2-3 drops of indicator i.e., diphenylamine were added and titrated against $0.5 \mathrm{~N}$ ferrous ammonium sulfate till the appearance of bottle green color.

$$
\begin{aligned}
& \text { Calculations: } \\
& \text { OC } \%=\frac{10 \text { (Blank }- \text { Titration value })}{\text { Blank }} \times \frac{0.003 \times 100}{\text { weight of a soil }}
\end{aligned}
$$

\subsubsection{Nitrogen estimation by Kjeldahl method}

Reagents for Nitrogen estimation of soil samples

(a) $0.32 \%$ potassium permanganate solution: $3.2 \mathrm{gm} \mathrm{KMnO}_{4}$ dissolved in $1000 \mathrm{ml}$ distilled water.

(b) $2.5 \%$ sodium hydroxide: $25 \mathrm{gm} \mathrm{NaOH}$ flakes dissolved in $1000 \mathrm{ml}$ distilled water.

(c) $0.02 \mathrm{~N}$ standard sulfuric acid.

(d) Mixed indicator: $0.07 \mathrm{gm}$ methyl red dissolved with $0.1 \mathrm{gm}$ bromocresol green in $100 \mathrm{ml}$ of $95 \%$ ethanol.

(e)Boric acid indicator solution: $20 \mathrm{gm}$ boric acid dissolved in about $700 \mathrm{ml}$ warm water. After cooling transferred to flask containing $200 \mathrm{ml}$ ethanol, to it $20 \mathrm{ml}$ mix indicator added. After mixing the contents $0.05 \mathrm{~N}$ $\mathrm{NaOH}$ added continuously until the color changes to reddish purple.

\section{Procedure for Nitrogen estimation by Kjeldahl method}

$2 \mathrm{ml}$ distill water, $10 \mathrm{ml} \mathrm{KMnO}_{4}$ and $10 \mathrm{ml} \mathrm{NaOH}$ is mixed with $2 \mathrm{gm}$ sample and placed in Kjeldahl assembly where digestion of sample and liberation of ammonia takes place, the liberated ammonia is collected in another flask in the assembly having boric acid and ammonia reacts with acid turning pink color of boric acid 
solution to green. $100 \mathrm{ml}$ of this green colored solution is then titrated against $0.02 \mathrm{~N} \mathrm{H}_{2} \mathrm{SO}_{4}$ till the color changes to pink.

Calculations:

$\mathrm{N}=\mathrm{R} \times 31.36 \mathrm{~kg} / \mathrm{hectare}$

3.5Estimation of morphological parameter of B.juncea

3.5.1Shoot \& Root Biomass of plant

The Shoot\& Root Biomass is the total biomass of a plant content in which the fresh or natural weight of plant sample was weighed (FW), then dries in an oven for 30 minutes at $108^{\circ} \mathrm{C}$ and then weighs again (DW) and kept in an oven until the weight becomes constant.

Calculation:

Total Biomass $=\mathrm{FW}+\mathrm{DW}$

\subsubsection{Shoot and Root length of B.juncea.}

Plants growing in P-deficient soil allocate a greater proportion of assimilates to root growth and tend to have fine roots of a small diameter and therefore a large surface area. Shoot and root length of plant was measured through regular interval of days.

\subsection{Estimation of physiochemical parameter of B.juncea.}

3.6.1Pigment analysis

$0.5 \mathrm{~g}$ of a plant sample was homogenize in a mortar and pestle with $10 \mathrm{ml}$ of $80 \%$ acetone, centrifuge it at $3000 \mathrm{rpm}$ and O.D was taken at $640 \mathrm{~nm}, 663 \mathrm{~nm}$ and $410 \mathrm{~nm}$.

Calculation:

$$
\begin{aligned}
& \text { Chlorophyll a }=\frac{12.7 \times \mathrm{A} 663-2.69 \times \mathrm{A} 645 \times \mathrm{V}}{1 \times 1000 \times \text { weight }} \\
& \text { Chlorophyll } \mathrm{b}=\frac{22.9 \times \mathrm{A} 645-4.68 \times \mathrm{A} 663 \times \mathrm{V}}{1 \times 1000 \times \text { weight }} \\
& \text { Total Chlorophyll }=\frac{20.2 \times \mathrm{A} 645-8.02 \times \mathrm{A} 663 \times \mathrm{V}}{1 \times 1000 \times \text { weight }}
\end{aligned}
$$

\subsubsection{Amino acid estimation by Ninhydrin method}

$0.5 \mathrm{~g}$ of sample was homogenized in $5 \mathrm{ml}$ of $3 \%$ Sulfosalicyclic acid and then filtered it and then $2 \mathrm{ml}$ of filtered solution, $2 \mathrm{ml}$ Glacial acetic acid, $2 \mathrm{ml}$ Ninhydrin and then $4 \mathrm{ml}$ Toulene was added water bath it for 1 hour until the brick red color occur, O.D was taken at $520 \mathrm{~nm}$.

\subsubsection{Protein estimation by Lowry method Reagent of protein estimation \\ Analytical reagents}

Analytical reagent was prepared by mixing $2 \mathrm{ml}$ of (b) with $100 \mathrm{ml}$ of (a)

a) $50 \mathrm{ml} 2 \% \mathrm{Na}_{2} \mathrm{CO}_{3}$ mixed with $50 \mathrm{ml} 0.1 \mathrm{~N} \mathrm{NaOH}$.

b) $10 \mathrm{ml}$ of $1.56 \% \mathrm{CuSO}_{4}$ mixed with $10 \mathrm{ml}$ of $\mathrm{Na}-\mathrm{K}$ tartarate solution.

Phosphorus is a component of the complex nucleic acid structure of plants, which regulates protein synthesis. $0.5 \mathrm{~g}$ sample crushed with $2 \mathrm{ml}$ distill water, $0.2 \mathrm{ml}$ of this protein solution mix with $2 \mathrm{ml}$ analytical reagent and incubate at room temperature for 10 minutes. Then add $0.2 \mathrm{ml}$ of Folin \& ciocateu's reagent and incubate for 30 minutes and O.D. was taken at $660 \mathrm{~nm}$.

\section{Result and Discussion}

The experiment was carried out by using $200 \mathrm{~g}$ of soil sample treated with Rock phosphate \& Tri calcium phosphate with a range of concentration between $0.2 \mathrm{~g}$ to $0.8 \mathrm{~g}$ and studied the requirement of the concentration of rock phosphate and tri calcium phosphate useful for plant growth. Here black mustard seed Brassica juncea has used for the experiment. After plantation of seeds, growth comes after three days. Every ten days of interval different physicochemical parameters of soil have been analyzed and biochemical parameters like amino acid, protein estimation for plant was also analyzed. Different experimental set up for tri-calcium phosphate and rock phosphate has shown in fig 2 and 3. 


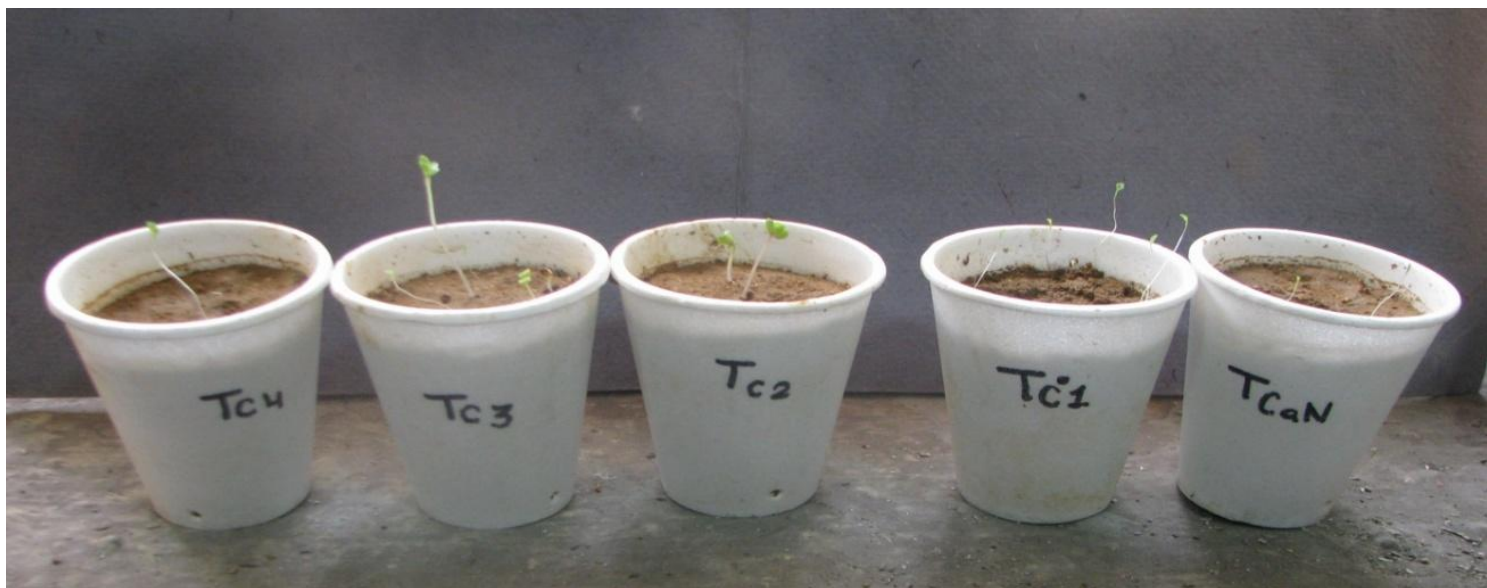

Fig. 2: Plant soil treated with Tri calcium phosphate

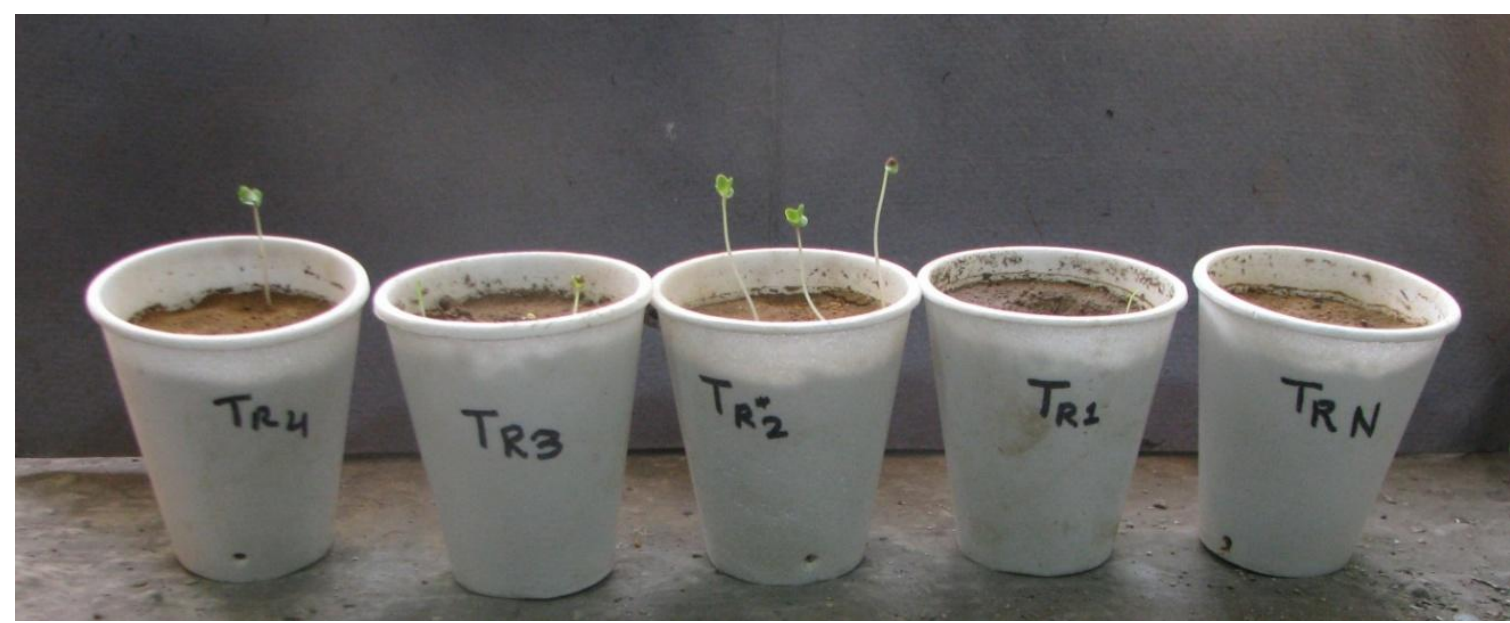

Fig 3: Plant soil treated with Rock phosphate

The following parameters of soil treated with Tri calcium phosphate \& Rock phosphate such as $\mathrm{pH}$, $\mathrm{EC}$, moisture, ash were analyzed. The $\mathrm{pH}$ of control in tri-calcium phosphate and rock phosphate is 6.16 . In tricalcium phosphate $\mathrm{pH}$ is lowered from $\mathrm{C} 1(\mathrm{pH}=6.15)$ to $\mathrm{C} 4(\mathrm{pH}=6.02)$ and $\mathrm{R} 4(\mathrm{pH}=5.92)$ to $\mathrm{R} 1(\mathrm{pH}=6.01)$ in rock phosphate from its original value that is the control shown in table 3 and 4. Electrical conductivity of soil sample increased gradually by addition of rock phosphate \& Tri-calcium phosphate i.e. highest EC observed by addition of rock phosphate in R2 was 95.4and of tri-calcium phosphate in C2 was 109.67 in compare to control i.e. 36.7 was observed. Moisture content of control in tri calcium phosphate and rock phosphate was 0.0107 respectively. The highest moisture content in tri-calcium phosphate was $\mathrm{C} 1(0.0105)$ and least in $\mathrm{C} 3(0.0028)$. Similarly highest moisture content in rock phosphate was R2 (0.0163) and least in R4 (0.016).Ash content of control in tri calcium phosphate and rock phosphate is 0.0791 respectively. The highest ash content in tricalcium phosphate was C4 (0.0821) and least was C3 (0.061). Similarly highest ash content in rock phosphate was R2 (0.0827) and least is R3 (0.0703). The overall values presented in table 3 and 4 and figure 4 and 5 reflects the graphical variation.

TABLE: 3 Parameter of soil sample treated with tri calcium phosphate

\begin{tabular}{|l|l|l|l|l|}
\hline sample & $\mathrm{P}^{\mathrm{H}}$ & EC & Moisture & Ash \\
\hline $\mathrm{C} 1$ & 6.15 & 104.00 & 0.0105 & 0.066 \\
\hline $\mathrm{C} 2$ & 6.12 & 109.67 & 0.0096 & 0.0778 \\
\hline $\mathrm{C} 3$ & 6.09 & 105.56 & 0.0028 & 0.061 \\
\hline $\mathrm{C} 4$ & 6.02 & 105.00 & 0.0036 & 0.0821 \\
\hline $\mathrm{CN}$ & 6.16 & 36.7 & 0.0107 & 0.0791 \\
\hline
\end{tabular}

$* \mathrm{C} 1=0.2 \mathrm{~g}$ conc., $\mathrm{C} 2=0.4 \mathrm{~g}$ conc., $\mathrm{C} 3=0.6 \mathrm{~g}$ conc., $\mathrm{C} 4=0.8 \mathrm{~g}$ conc., $\mathrm{CN}=\mathrm{Control}$ 
Fig.4: Variation in soil parameter treated with $\mathrm{CP}$

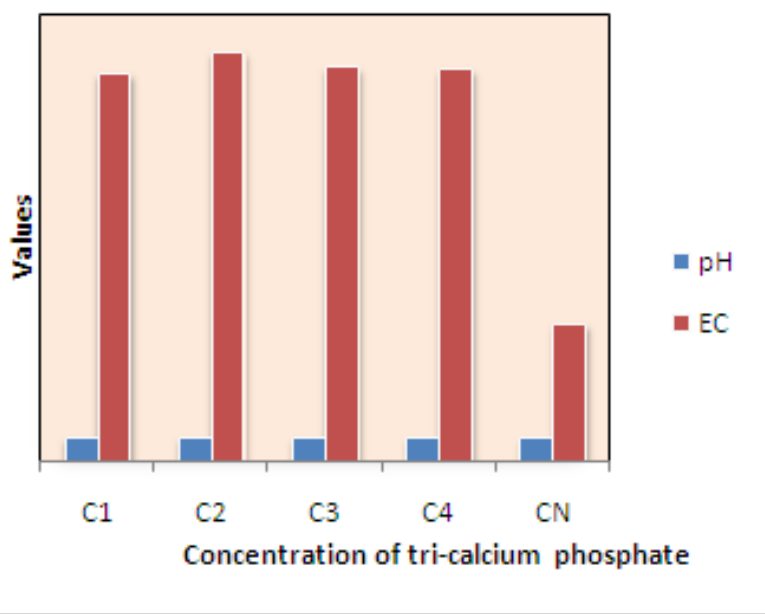

Fig.5: Variation in soil parameter treated with RP

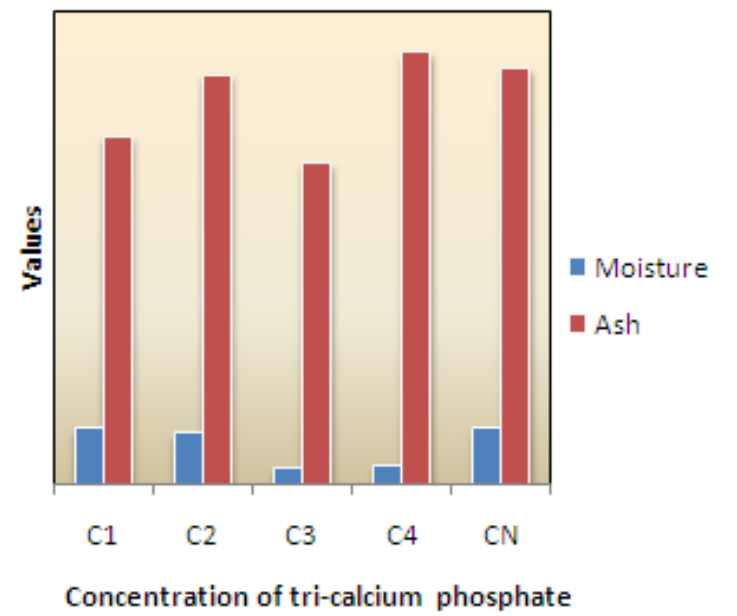

TABLE: 4 Parameter of soil sample treated with rock phosphate

\begin{tabular}{|l|l|l|l|l|}
\hline Sample & $\mathrm{P}^{\mathrm{H}}$ & $\mathrm{EC}$ & Moisture & Ash \\
\hline R1 & 6.01 & 83.5 & 0.0119 & 0.0703 \\
\hline R2 & 5.99 & 95.4 & 0.0163 & 0.0827 \\
\hline R3 & 5.97 & 91.2 & 0.0021 & 0.0729 \\
\hline R4 & 5.92 & 78.0 & 0.016 & 0.0814 \\
\hline RN & 6.16 & 36.7 & 0.0107 & 0.0791 \\
\hline
\end{tabular}

$* \mathrm{R} 1=0.2 \mathrm{~g}$ conc., $\mathrm{R} 2=0.4 \mathrm{~g}$ conc., $\mathrm{R} 3=0.6 \mathrm{~g}$ conc., $\mathrm{R} 4=0.8 \mathrm{~g}$ conc., $\mathrm{RN}=$ Control

Fig.6: Variation in soil parameter treated with RP

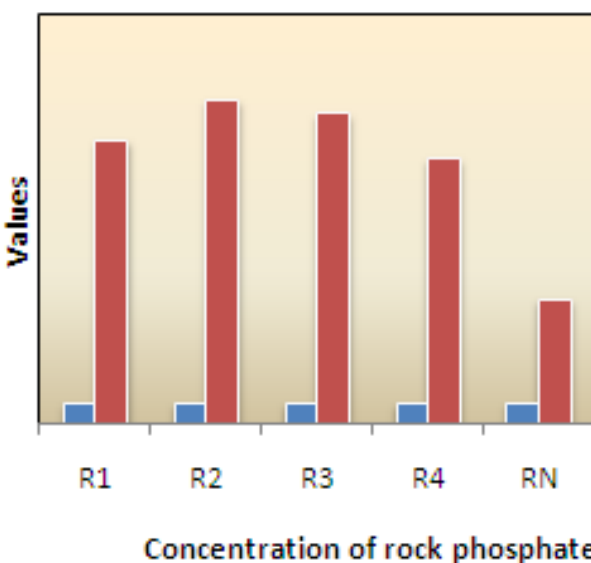

Concentration of rock phosphate
Fig.7: Variation in soil parameter treated with RP
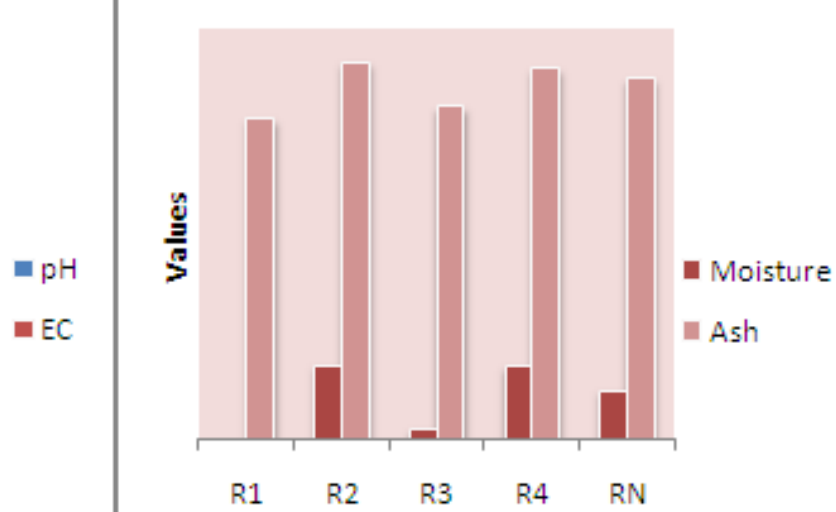

Concentration of rock phosphate

The results from the data analysis of germination (table: 5\& fig: $8 \& 9$ ) reflects that the rock phosphate $\&$ tri-calcium phosphate does not affect much more for mustard seed germination. For a wide range of germination percentage may be due to quality of seeds or may be external factors like temperature. So it can be concluded that the germination percent increased as organic carbon and $\mathrm{N}$ increased while available $\mathrm{P}$ had no significant effect on germination of mustard seed.

TABLE.5: Effect of Tri calcium phosphate \& Rock phosphate on germination

\begin{tabular}{|l|l|l|l|l|l|l|l|l|l|}
\hline Sample & C1 & C2 & C3 & C4 & N & R1 & R2 & R3 & R4 \\
\hline \% of germination & 80 & 100 & 90 & 80 & 100 & 80 & 90 & 80 & 100 \\
\hline
\end{tabular}


Fig.8:\% of germination when treated with CP Fig.9:\% of germination when treated with RP
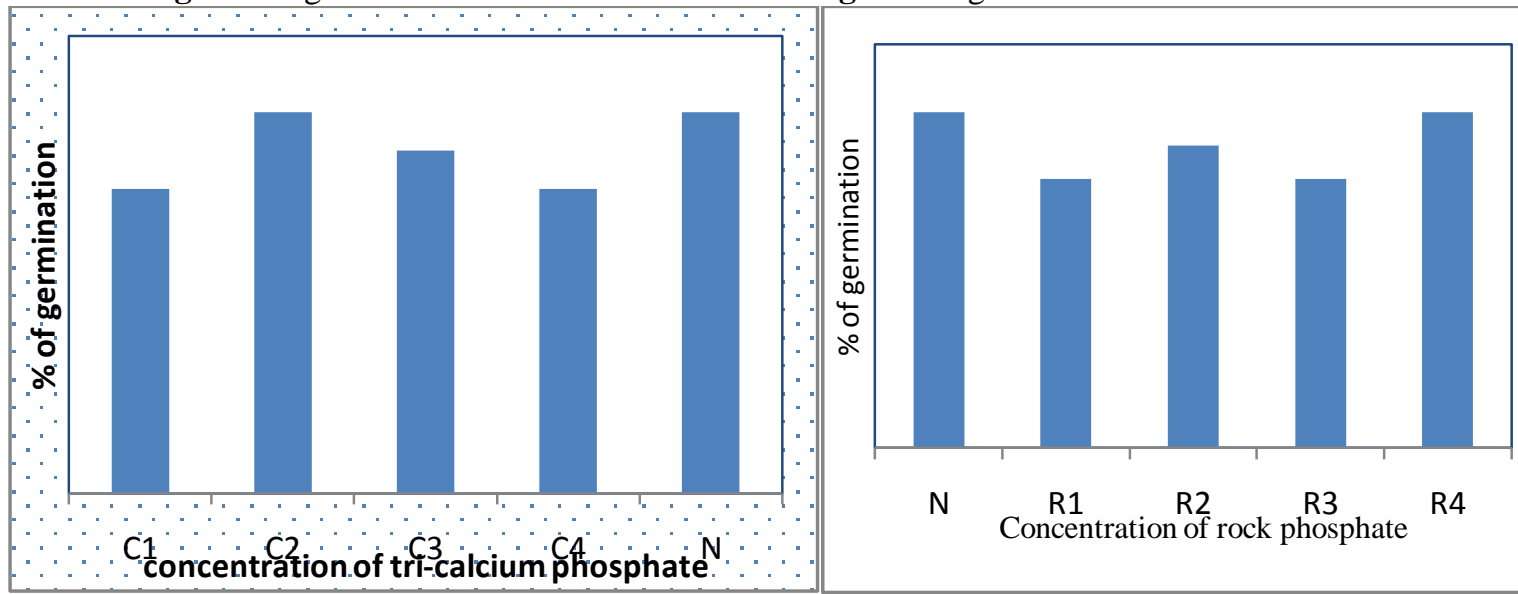

The use of rock phosphate \& tri- calcium phosphate has shown major effect in increasing root length of mustard plant as compare to control, concentration of $\mathrm{C} 1, \mathrm{C} 4 \& \mathrm{R} 2$, R4 has maximum root length as shown in table.6.Enrichment of soil with phosphorous has an effect in biomass of the plant and tri-calcium phosphate has shown in good result in shoot \& root biomass of mustard plant in compare to rock phosphate and C3 concentration has a highest value i.e. 0.1789 .

TABLE.6: Effect of Tri calcium phosphate \& Rock phosphate on Shoot and Root length of Brassica juncea.

\begin{tabular}{|c|c|c|c|c|c|}
\hline \multirow[t]{2}{*}{ Sample } & \multicolumn{2}{|l|}{$5^{\text {th }}$ day } & \multicolumn{2}{|l|}{$10^{\text {th }}$ day } & \multirow{2}{*}{$\begin{array}{lr}\text { Shoot \& } & \text { Root } \\
\text { biomass(after } & 10 \\
\text { days) } & \end{array}$} \\
\hline & $\begin{array}{l}\text { Shoot } \\
\text { length }\end{array}$ & Root length & Shoot length & Root length & \\
\hline $\mathrm{C} 1$ & 6 & 2.5 & 11 & 4 & 0.1096 \\
\hline $\mathrm{C} 2$ & 4 & 1.4 & 10 & 3.5 & 0.1348 \\
\hline $\mathrm{C} 3$ & 5 & 2.2 & 9.5 & 4.3 & 0.1789 \\
\hline $\mathrm{C} 4$ & 4.5 & 1.3 & 10.5 & 3.7 & 0.1051 \\
\hline $\mathrm{N}$ & 1.5 & 0.8 & 7.8 & 3.4 & 0.0856 \\
\hline R1 & 3 & 1.2 & 8.5 & 3.2 & 0.0819 \\
\hline $\mathrm{R} 2$ & 4 & 1.5 & 10.5 & 4.2 & 0.1138 \\
\hline R3 & 2 & 1.1 & 8.5 & 4.0 & 0.0932 \\
\hline $\mathrm{R} 4$ & 3.5 & 1.7 & 9.5 & 4.3 & 0.095 \\
\hline
\end{tabular}

Fig.8: Shoot \& Root biomass of Brassica juncea $\mathrm{CP}$

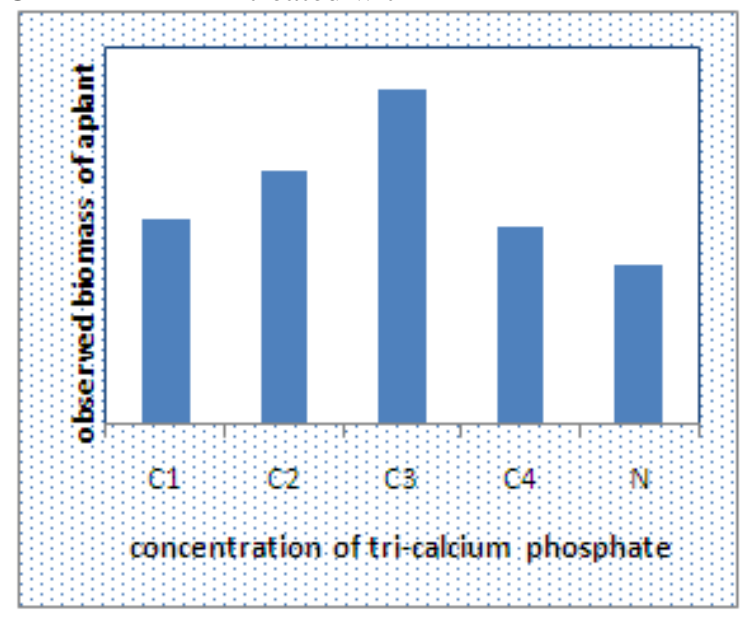

Fig.9: Shoot \& Root biomass of B.juncea treated with

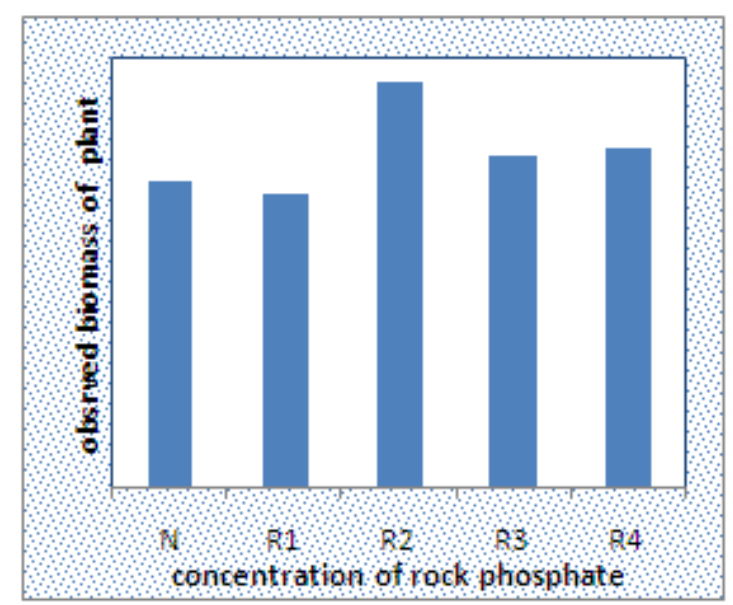

The pigment value of plant after treated with different concentration of tri-calcium phosphate and rock phosphate were analyzed at different wavelength i.e. $640 \mathrm{~nm}, 410 \mathrm{~nm} \& 663 \mathrm{~nm}$. The phosphorous enrichment had no effect on the chlorophyll content but as the significant amount of $\mathrm{N}$ present in the soil then combining with this $(\mathrm{N}+\mathrm{P})$ has effect on the chlorophyll contain (menendez et.al 2002). The highest pigment value of $\mathrm{C} 3$ was shown in table.7. \& fig.10\&11. And tri-calcium phosphate has shown better result in compare to rock phosphate. 
TABLE.7: Pigment observe of plant at a different O.D treated with RP \&CP

\begin{tabular}{|l|l|l|l|}
\hline Sample & Chlorophyll a & Chlorophyll b & Total chlorophyll \\
\hline C1 & -0.00341 & -0.00861 & 0.03128 \\
\hline C2 & 0.004825 & -0.04232 & 0.085172 \\
\hline C3 & 0.03032 & -0.01416 & 0.26002 \\
\hline C4 & 0.01926 & -0.09479 & 0.180978 \\
\hline N & 0.00842 & -0.06137 & 0.128821 \\
\hline R1 & -0.00453 & -0.00694 & 0.030322 \\
\hline R2 & 0.004841 & -0.03127 & 0.065956 \\
\hline R3 & 0.004795 & -0.0567 & 0.127595 \\
\hline R4 & 0.008043 & -0.06105 & .129104 \\
\hline
\end{tabular}

$* \mathrm{R} 1=0.2 \mathrm{~g}$ conc., $\mathrm{R} 2=0.4 \mathrm{~g}$ conc., $\mathrm{R} 3=0.6 \mathrm{~g}$ conc., $\mathrm{R} 4=0.8 \mathrm{~g}$ conc., $\mathrm{N}=\mathrm{Control} \mathrm{C} 1=0.2 \mathrm{~g}$ conc., $\mathrm{C} 2=0.4 \mathrm{~g}$ conc., $\mathrm{C} 3=0.6 \mathrm{~g}$ conc., $\mathrm{C} 4=0.8 \mathrm{~g}$ conc.

Fig.10 Pigment was observed of plant treated with $\mathrm{CP}$

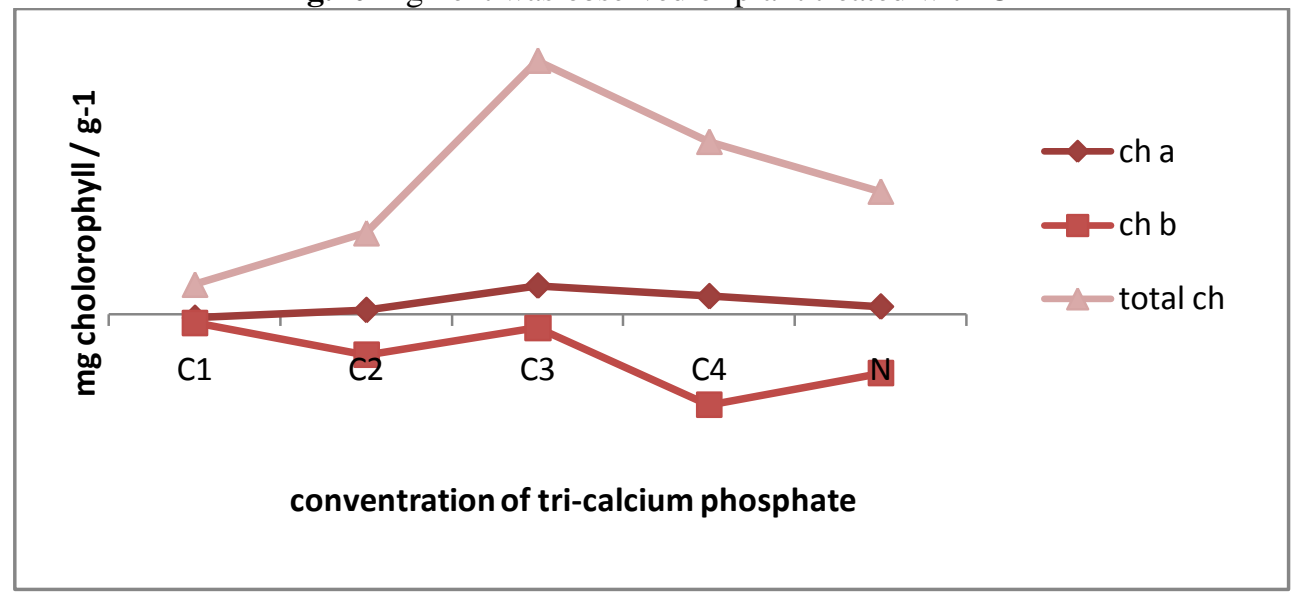

Fig.11: Pigment observed of plant treated with RP

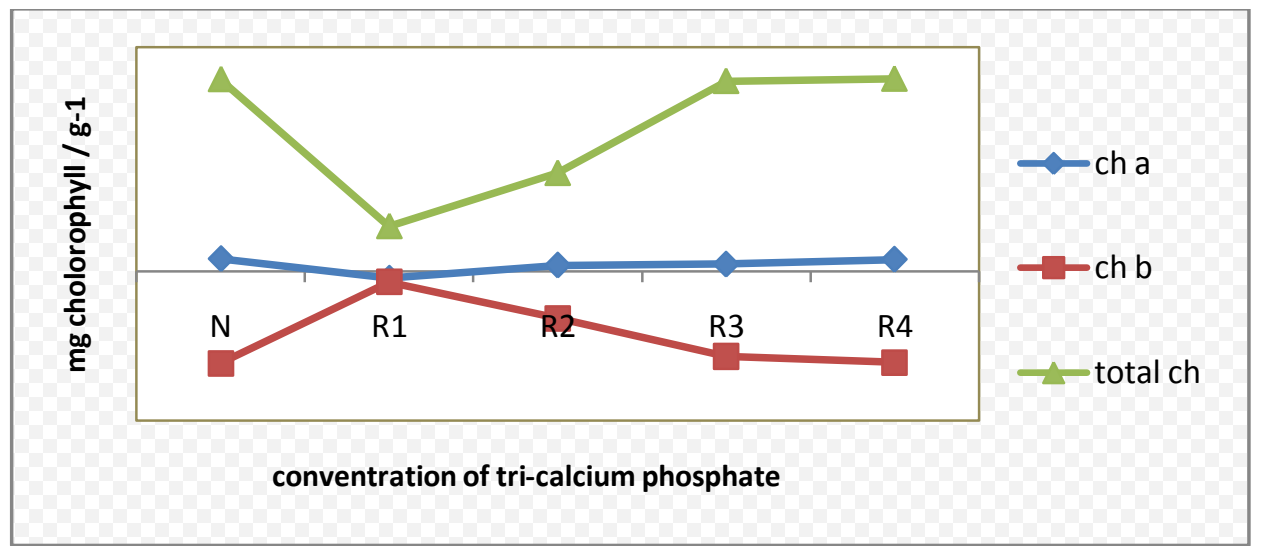

Phosphorus is a component of the complex nucleic acid structure of plants, which regulates protein synthesis amino acid content of mustard plant after mixed with the tri-calcium phosphate, has constantly higher than treatment with rock phosphate. The tri-calcium phosphate having free phosphate ions so amino acid contain was more than the rock phosphate as shown in fig. $12 \& 13$ and table. 8 The highest amino acid content by the C4(2.56)

TABLE.8: Plant treated with rock phosphate \&tri calcium phosphate having following parameter*N=Control

\begin{tabular}{|l|l|}
\hline Sample & Amino acid content \\
\hline $\mathrm{C} 1$ & 2.179 \\
\hline $\mathrm{C} 2$ & 2.4 \\
\hline $\mathrm{C} 3$ & 1.577 \\
\hline $\mathrm{C} 4$ & 2.56 \\
\hline $\mathrm{N}$ & 2.09 \\
\hline $\mathrm{R} 1$ & 1.67 \\
\hline $\mathrm{R} 2$ & 2.09 \\
\hline $\mathrm{R} 3$ & 2.12 \\
\hline
\end{tabular}




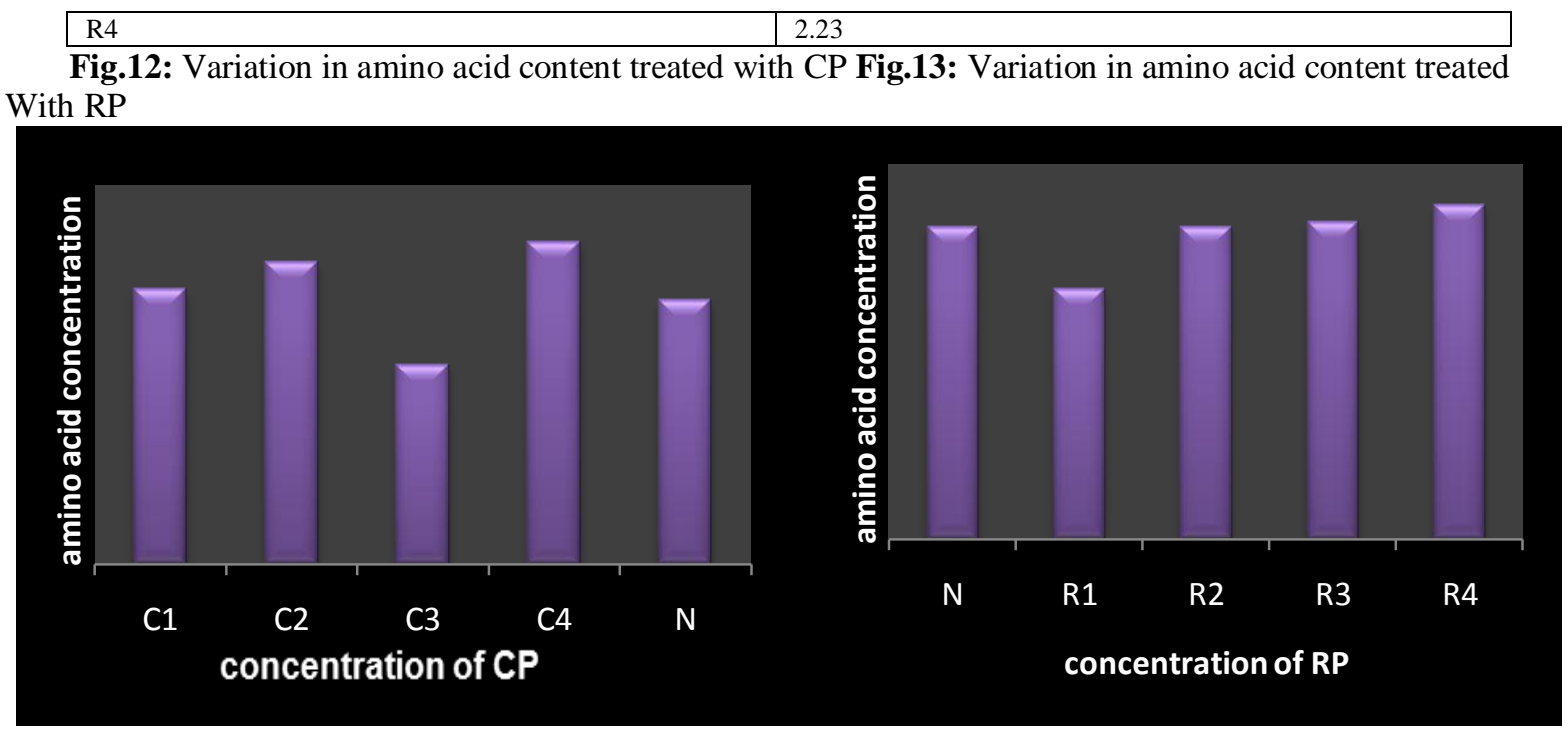

Total organic carbon of tri-calcium phosphate and rock phosphate mixed soil were estimated on initial, 5 th and $10^{\text {th }}$ days of interval. The highest TOC value was observed on $10^{\text {th }}$ day i.e. (C1)9.64 of calcium phosphate and R1 (10.17) on $1^{\text {st }}$ day in rock phosphate, as in table 5 and in fig. $14 \& 15$. The least TOC value was observed on 5th day i.e.C3 (4.28) in calcium phosphate and R4 (4.28) on $5^{\text {th }}$ day in rock phosphate.

TABLE 9: \% of TOC of soil sample of a plant treated with CP \&RP at regular interval of days

\begin{tabular}{|l|l|l|l|}
\hline Sample & 0 day & 5 th day & 10 th day \\
\hline C1 & 6.96 & 5.35 & 9.64 \\
\hline C2 & 7.1 & 6.9 & 8.57 \\
\hline C3 & 6.43 & 4.28 & 6.43 \\
\hline C4 & 8.57 & 6.42 & 7.5 \\
\hline N & 9.64 & 5.35 & 7.5 \\
\hline R1 & 10.17 & 4.28 & 8.57 \\
\hline R2 & 8.16 & 5.35 & 8.57 \\
\hline R3 & 7.5 & 6.42 & 7.5 \\
\hline R4 & 8.57 & 6.42 & 4.28 \\
\hline
\end{tabular}

$* \mathrm{C} 1=0.2 \mathrm{~g}$ conc., $\mathrm{C} 2=0.4 \mathrm{~g}$ conc., $\mathrm{C} 3=0.6 \mathrm{~g}$ conc., $\mathrm{C} 4=0.8 \mathrm{~g}$ conc., $\mathrm{N}=\mathrm{Control} \mathrm{R} 1=0.2 \mathrm{~g}$ conc., $\mathrm{R} 2=0.4 \mathrm{~g}$ conc., $\mathrm{R} 3=0.6 \mathrm{~g}$ conc., $\mathrm{R} 4=0.8 \mathrm{~g}$ conc. $\mathrm{CP}=$ tri-calcium phosphate, $\mathrm{RP}=$ rock phosphate

Fig.14: \% of TOC content of plant soil treated with CP Fig.15: \% of TOC of plant soil treated with RP
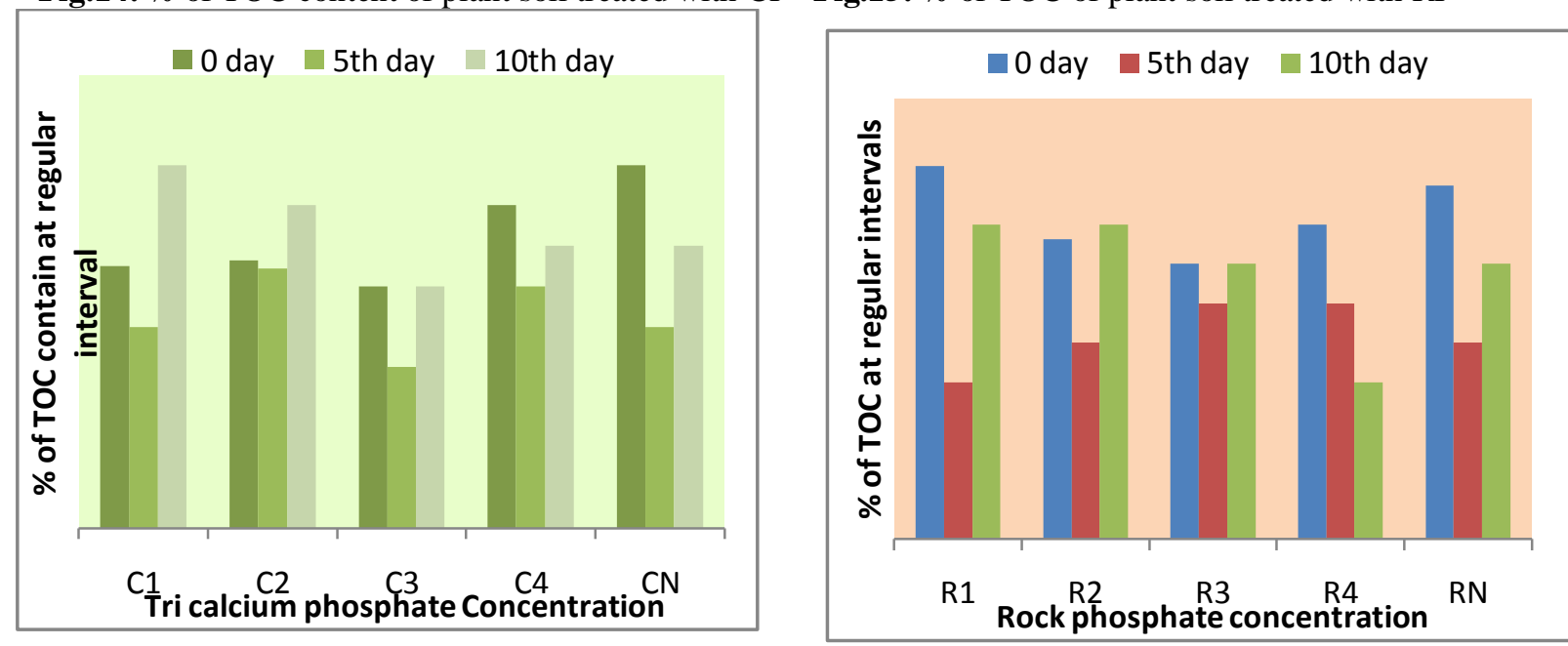

Nitrogen estimation of soil samples having different concentration of both phosphate compounds was done by Kjeldahl method at regular interval and found that nitrogen concentration was increasing after adding tri-calcium phosphate and rock phosphate at initial measurement except R2, where the concentration was decreased. At $20^{\text {th }}$ day highest nitrogen concentration was observed in R4. Nitrogen concentration at $5^{\text {th }}$ day is 
gradually decreases except control, R2 and R4 and after in $10^{\text {th }}$ day and $20^{\text {th }}$ day it becomes increased. The result was shown in tabular form at below and graphical variation shown in fig.16\&17.

TABLE.10: Nitrogen estimation at regular interval of days of plant soil treated with RP \& CP.

\begin{tabular}{|c|c|c|c|c|}
\hline Sample & 0 day & $5^{\text {th }}$ day & $10^{\text {th }}$ day & $20^{\text {th }}$ day \\
\hline $\mathrm{C} 1$ & 14.37 & 9.76 & 10.34 & 12.54 \\
\hline $\mathrm{C} 2$ & 14.73 & 10.34 & 11.6 & 10.976 \\
\hline C3 & 11.6 & 10.976 & 11.29 & 12.85 \\
\hline $\mathrm{C} 4$ & 12.23 & 9.72 & 12.23 & 12.54 \\
\hline $\mathrm{N}$ & 10.35 & 10.976 & 11.29 & 11.29 \\
\hline $\mathrm{R} 1$ & 10.976 & 10.66 & 11.29 & 10.34 \\
\hline R2 & 9.72 & 10.34 & 12.85 & 12.85 \\
\hline R3 & 14.42 & 9.408 & 13.17 & 11.91 \\
\hline R4 & 11.91 & 12.54 & 12.85 & 14.42 \\
\hline
\end{tabular}

$* \mathrm{R} 1=0.2 \mathrm{~g}$ conc., $\mathrm{R} 2=0.4 \mathrm{~g}$ conc., $\mathrm{R} 3=0.6 \mathrm{~g}$ conc., $\mathrm{R} 4=0.8 \mathrm{~g}$ conc., $\mathrm{N}=$ Control $\mathrm{C} 1=0.2 \mathrm{~g}$ conc., $\mathrm{C} 2=0.4 \mathrm{~g}$ conc., $\mathrm{C} 3=0.6 \mathrm{~g}$ conc., $\mathrm{C} 4=0.8 \mathrm{~g}$ conc.

Fig.16: Variation in N2 concentration at regular days when treated with $\mathrm{CP}$

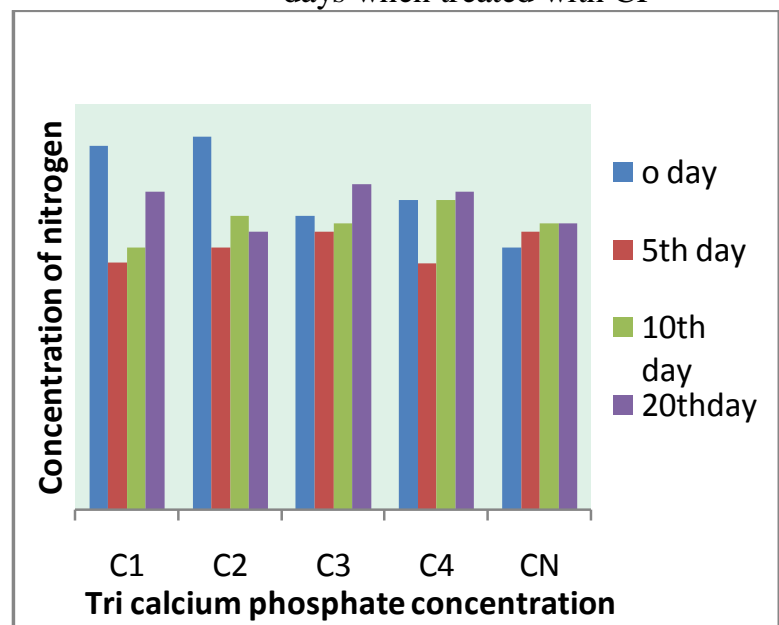

Fig.17: Variation in N2 concentration at regular interval of of days when treated with RP

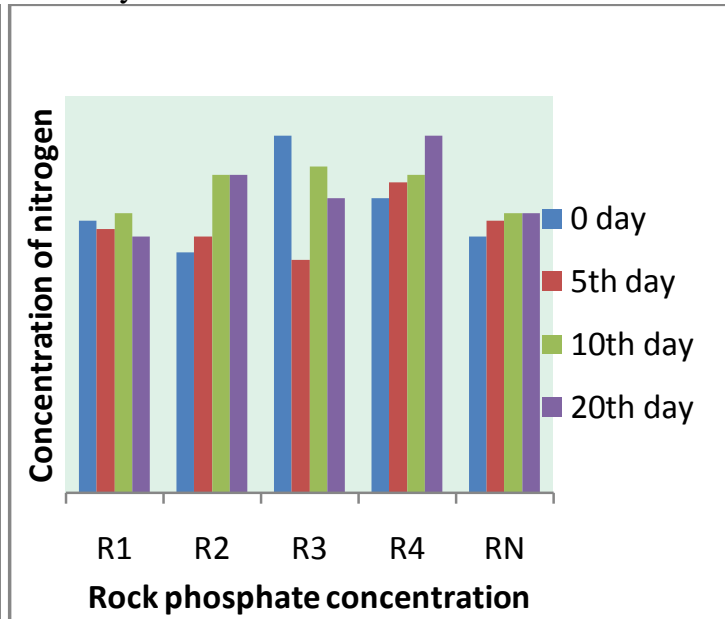

\section{Conclusion}

The comparative studies between rock phosphate and calcium phosphate on the growth and the biochemistry of Brassica juncea was concluded by studying physiochemical and biochemical properties of plant as well as physiochemical properties of the soil was estimated. The availability of phosphorus in the soil depends largely on the $\mathrm{pH}$ value. The $\mathrm{pH}$ of the soil treated with tri-calcium phosphate and rock phosphate was decreased slightly from original value \& EC was increased. The rock phosphate \&tri-calcium phosphate doesn't favor in mustard seed germination as nutrients doesn't factor in germination percentage.Tri-calcium phosphate has shown in good result in root length and also in shoot \& root biomass of mustard plant in compare to rock phosphate and $\mathrm{C} 3$ concentration has a highest value of biomass i.e. 0.7629. The pigment value of plant after treated with different concentration of tri-calcium phosphate and rock phosphate were good but the highest value of C3 .Amino acid content of mustard plant with the tri-calcium phosphate has constantly higher than the rock phosphate due to presence of free phosphate ions in tri-calcium phosphate.

Continuously at a regular interval of days TOC and Nitrogen concentration was evaluated to study the impact of rock phosphate \& calcium phosphate on the soil health. Highest TOC value was observed on $10^{\text {th }}$ day i.e. (C1)9.64 in calcium phosphate and R1 (10.17) on $1^{\text {st }}$ day in rock phosphate\& the least TOC value was observed on 5th day i.eC3 (4.28) in calcium phosphate and R4 (4.28) on $5^{\text {th }}$ day in rock phosphate. Nitrogen concentration at $5^{\text {th }}$ day is gradually decreases except control, R2 and R4 and after in $10^{\text {th }}$ day and $20^{\text {th }}$ day it becomes increased.

\section{Acknowledgement}

It is indeed a great pleasure for me to acknowledge with a sense of indebtedness and gratitude the invaluable support extended by various persons in different stages of experimental work and completion of my project work I,SandhyaBuddh a student of M.Sc Biotechnology department in Boston college for professional 
studies, Gwalior would like to place on record my deep sense of gratitude to Dr. Reena Jain, Head of the Department of Biotechnology for providing me such a golden opportunity to undertake this dissertation work.

I am extremely grateful to Dr.Amalendu Sinha, Director CIMFR for his co-operation in providing me the opportunity to take up six month training in such a highly esteemed and well groomed laboratory as CIMFR.

I would also like to place on record my sense of gratitude to Dr L.C Ram, Head Environmental Division for his valuable guidance and extending all the facilities to complete the project on time.

Any form of appraisal would not be correct to describe the role of my guide Dr. V.A Selvi as the whole work was carried out on her guidance. She had been supportive all through and time to time extended valuable suggestions for my improvement. She always showed keen interest and appreciated my endeavor as a result of which I could accomplish what is needed for the project.

I would also like to pay my heartiest thanks to my parents for their constant moral support without which I couldn't have completed my project.

Lastly I would also like to pay my thanks to research scholars, Diptangshu, Ilyas, all the staffs and research trainees of C.F.R.I. for their sincere help and co-operation in completion of my dissertation work.

Reference

[1]. Mullins, G.L., and B.F. Hajek (1996) Phosphorous accumulation and loss from Alabama soils receiving poultry litter, Alabama Ag. Exp. Sta. Bull. No. 631.

[2]. Ratti N, Kumar S, Verma HN, Gautam SP(2001),Improvement in bioavailability of tricalcium phosphate to Cymbopogonmartinii var. motia by rhizobacteria, AMF and Azospirillum inoculation. 156(2):145-9

[3]. A.L. Elliott, J.G. Davis, R.M. Waskom, Extension water resource specialist; J.R. Self, director, Soil, Water and Plant Testing Lab; and D. K. Christensen, research associate, department of horticulture. 7/05. Reviewed 10/09.

[4]. Sonam Sharma*, Vijay Kumar and Ram BabuTripathi (2011) Isolation of Phosphate Solubilizing Microorganism (PSMs) From Soil J. Microbiol.Biotech. Res. 1 (2):90-95

[5]. HosseinMirseyedHosseini, Sara Khayami, HosseinBesharati andSanam.Bybord( 2010) Study of the effects of rock phosphate application with phosphate solublizing bacteria on P availability for corn World Congress of Soil Science, Soil Solutions for a Changing World

[6]. Bowen G.D. and Rovira A.D. (1999)The rhizosphere and its management to improve plant growth. Advances in Agronomy. 66, 1 102.

[7]. Abioye O. Fayiga,Lena Q. Ma(2006) Using phosphate rock to immobilize metals in soil and increase arsenic uptake by hyperaccumulatorPterisvittata, Science of the Total Environment 359 17-25

[8]. Mike Bolland(1989), Effectiveness of Rock phosphate, Journal of agricultural, 30(4):155-4

[9]. Kondracka and Rychter(1997), The role of P; recycling processes during photosynthesisin phosphate-deficient bean plants, Journal of Experimental Botany, Vol. 48, No. 312, pp. 1461

[10]. (2011)Plant and microbial strategies to improve the phosphorus efficiency of agriculture Plant Soil (2011) 349:121-156

[11]. Z. Rengel (2008) Bioavailability of Phosphorus and Micronutrients in the Soil-Plant-Microbe Continuum, 5th International Symposium ISMOM 2008 - November 24th - 28th

[12]. G.M. Pierzynski(2000)Methods of Phosphorus Analysis for Soils,Sediments, Residuals, and Waters, Department of Agronomy, ISBN: 1-58161-396-2

[13]. Margarita menendez (2002)Effects of Phosphorus Nutrition on Ribulose-1,5-Bisphosphate Carboxylase Activation, Photosynthetic Quantum Yield and Amounts of Some Calvin-Cycle Metabolites in Spinach Leaves, Australian Journal of Plant Physiology 13(2) $221-237$

\section{INSTRUMENTS HANDLED}

\section{Centrifuge (Biofuge 28RS Heraeussepatech centrifuge)}

It is an apparatus that rotates at high speed and separates substances/particles on the basis of mass and density by means of centrifugal force. The centrifugal force is noted in revolutions per minute (rpm) of angular speed. A centrifuge consists of a head, which is rapidly revolved by an upright motor. Generally four metal cups/containers are attached to the head for holding tubes or other containers of the material from which the particulate matter is to be separated. During centrifugation, liquid containing particulate matter is kept in tubes, runs at a particular speed and when centrifugation is complete, the particulate mater gets settle at the bottom of the tubes. Various types of centrifuge commonly used are low-speed (clinical centrifuge), high-speed or superspeed and ultracentrifuges. The highest speed limit of low-speed, high-speed and ultracentrifuges are $5000 \mathrm{rpm}$, $18000 \mathrm{rpm}$ and 20000 to $60000 \mathrm{rpm}$ respectively. These are used separation of particles dispersed in suspended matter, separation of mixtures of liquids varying in their density or solids from liquids or concentrating microorganisms in varying samples for enzymatic studies.

\section{Electronic Balance (WM - AclairDutt ADN-200W)}

The electronic balance is a balance, which has only one pen on which the weighing substances are placed. It is a surrounded by a glass chamber with two sliding doors. The balance should be kept in a place free from any vibration, air thrust, strong ray of light, suspended dust particles, acid and chemical fumes, strong heat etc. and air conditioned room is preferable for this purpose. Fluorescent light is well suited in the laboratory for fair reading. 
Before using the balance it should be cleaned using a soft duster. The pointer is adjusted to zero. The substance to be weighed is kept in the pan. The reading that comes on the displayed screen is the correct weight of the substance. It should be noted that no air should pass through during the operation of the balance

\section{Spectrophotometer (spectronic 20 Bausch \& Lomb)}

It is an instrument used for counting population of bacteria, based on the principle of turbidity determination. Turbidity or optical density is the cloudiness of the suspension. The more turbid a suspension, the less light will be transmitted through it. In other words, the amount of light absorbed and scattered is proportional to the mass of cells in the light path. As bacteria grow in a broth, the clear broth becomes turbid. Since the turbidity increases as the number of cells increase, this indicator is used as an indicator of bacterial density in the broth. Turbidity is also useful for standardizing the population densities of bacterial cultures of clinical significance.

It is a laboratory instrument, which helps in finding out the optical density of different solutions. It has varied applications in the Qualitative analysis of sample purity, DNA and protein quantification, cell density, measurements and assay involving enzyme-catalyzed fractions. It is based on the simple principle that various compounds will differentially absorb specific wavelength of light in the UV (200 to $300 \mathrm{~nm}$ ) visible (400 to 700 $\mathrm{nm}$ ) or near infrared (700 to $900 \mathrm{~nm}$ ) ranges. Photometric assays can involve the direct measurement of the absorbance of a sample at a given wavelength, all spectrophotometers employs the basic structural components designed to detect variations in absorption wavelengths and concentrations.

The general components common to most spectrophotometer systems include a light source wavelength selector, fixed or adjustable slit, cuvette, photocell and analog or digital read out. Basically, The light source (specific for either UV or visible ranges) emits light that is passed through the wavelength selector, usually prism, and diffraction grating. Or set of screening filters where a specific wavelength of monochromatic light is selectively generated (defined by its maximum emission at this wavelength) the light is then directed towards a thin slit (usually adjustable) to regulate its relative intensity before it passes through a cuvette containing the sample of interest. Cuvettes differ with respect to their absorbance characteristics, and one must be careful to be constituent in making all measurements. Finally, absorbance is detected by the photocell, which uses the electron in the refracted light to generate an electric current that can be amplified and measure to yield an absorbance value, or optical density (OD), for the given sample. The OD reading is corrected against a blank, which is usually referred to as control (control contains all the reagents in the experimental sample except the test compound) to obtain a true measure of the optical density of the sample.

The data obtained from the spectrophotometeric analysis often serve an important role in the determination of various experimental parameters and results. Moreover, when used in conjunction with results from other techniques, spectrophotometric data serve as a powerful analytic function.

\section{Incubator}

An incubator is very similar to an oven in construction and consists of an insulated cabinet fitted with a heating element at the bottom. The temperature of the incubator is maintained at the desired level by an automatic device called thermostat which cuts the connection of when the temperature reaches the point for which the thermostatic set, and turns it on again when the temperature falls below that point. The incubator is properly ventilated by the perforated shelves. They are provided with double doors, the inner one made of glass so that the contents of the incubator may be viewed without admitting outside air. An incubator is used for the incubation (i.e. culturing of microorganisms at a constant temperature favourable to the growth and development) of various microorganisms. Most incubators use dry heat for maintaining temperature Moisture can be supplied by placing a beaker of water init to retard dehydration of the medium, during the growth period of microorganisms.

\section{The pH meter (Orion Expandable ion Analyzer EA 940)}

The $\mathrm{pH}$ meter is a potentiometer that measures the potential developed between a glass electrode and a reference electrode. However in the modern instruments the 2 electrodes are frequently combined into one electrode, known as a combination electrode. It is a potentiometer measuring the electromotive force, of a construction cell formed from a reference electrode, the test solution and a glass electrode sensitive to $\mathrm{H}^{+}$. The term $\mathrm{pH}$ stands for potential of hydrogen while $\mathrm{pH}$ is defined as the negative logarithm of hydrogen ion concentration or activity. Glass electrode: It has a thin bulb, internally filled with a solution of Hal. Into this is suspended an Ag-Gal electrode via a platinum develops between the glass membranes, which depends on the $\mathrm{pH}$ of the solution in which it is immersed. The glass electrode in the test solution constitutes a half-cell and a reference electrode completes the measuring circuit. Calomel Electrode: This is the reference electrode; this is not sensitive to $\mathrm{H}^{+}$. It has a glass vessel containing a layer of liquid $\mathrm{Hg}$ and a layer of mercurous chloride paste (calomel). Connected to this is a platinum wire. The whole set up is suspended in a reservoir of concentrated 
potassium chloride solution. Electric contact is made by each of the electrode combinations with the test solutions at the test ends. Combined electrode: When both the glass and calomel electrodes are not separated but found one within the other, then such an electrode is referred to as combined electrode. The contact platinum wire extending from both the electrodes are connected to the potentiometer, which detects difference in the potential. This unit has a digital display, a switch for temperature adjustment, a selector for reading the $\mathrm{pH}$ and a calibration knob for standardization.

Principle: The two electrodes have their components in ionized state.

In both the electrodes, there are three equilibrium systems interacting with each other. If the 2 electrodes are connected the electrons move from one electrode to the other. Hence, upsetting the whole equilibrium. Therefore suitable changes takes place in ionization and steady state is established. The resulting current flow can be measured if the electrons are dipped into the solution or high $\mathrm{H}^{+}$ions or $\mathrm{OH}^{-}$ions concentration, the calomel electrode does not respond, but the equilibrium of the reaction at the glass electrode is affected. This results in the difference in electron concentration in the glass electrode, making it more positive or negative to the reference electrode, where the electron concentration is steady. The resulting current flow can be measured and this will give the measure of hydrogen ions present in the test solution.

In the $\mathrm{pH}$ which consists of an electrode sensitive to $\mathrm{H}^{+}$concentration, an electrical circuit is present which measures the $\mathrm{E}>\mathrm{M}>\mathrm{F}>$ developed across the electrode pair, which in turn depends the $\mathrm{H}^{+}$ion concentration and hence $\mathrm{pH}$. This current is fed into a calibrated dial, in such that the $\mathrm{pH}$ of the solution is read directly. A pH meter is calibrated using a solution of standard $\mathrm{pH}$, which should have a $\mathrm{pH}$ in the range in which the test solution is expected to lie. The $\mathrm{pH}$ is marked from 0 to 14 and can be displayed on the digital scale.

Standardization against a buffer of known $\mathrm{H}^{+}$concentration is required because the concentration Of the $\mathrm{H}^{+}$inside the bulb of the glass electrode changes with time. Adjustments for temperature are necessary because the relationship between measured potential and $\mathrm{pH}$ is temperature dependent.

Determination of $\mathrm{pH}$ of the given sample A $100 \mathrm{ml}$ beaker is rinsed with distilled water. The electrode is wiped dry using a filter paper and is then immersed in the test sample after mixing. The selection knob is put to $\mathrm{pH}$ position and $\mathrm{pH}$ is taken down from the digital display after value becomes constant. The electrode is removed from the sample and rinsed with distilled water, wiped dry and kept dipped in the beaker containing distilled water.

\section{Precautions}

Wash the bulb of the electrode before use. Always keep the bulb immersed in $\mathrm{KCl}$ solution when not in use. Calibration is done using

\section{Dry Heat Sterilization: Hot air oven}

An oven is based on the principle where the sterilization is accomplished by dry heat or hot air. Dry heat removes water from microorganisms while moist heat adds water to them. In addition, moist heat has greater penetrating power than dry heat and it causes coagulation of proteins.

Hot air oven are most commonly used for sterilizing glassware like Petri dishes, test tubes, pipettes, metal instruments that can tolerate prolonged heat exposure, oils, powders, waxes and other articles that are either spoiled or not effectively sterilized by the moist heat of the autoclave. Sterilization is accomplished by the exposure of items to $150^{\circ} \mathrm{C}-180^{\circ} \mathrm{C}$ for 2 to 4 hours.

An oven consists of an insulated cabinet which is held at a constant temperature by means of an electric heating mechanisms and thermostat. It is fitted with a fan to keep the hot air circulating at a constant temperature and thermometer for recording the temperature of the oven. For normal sterilization work, the oven should be operated at $160^{\circ} \mathrm{C}$ and most glassware will require a period of two hours for total sterilization. For proper circulation of the hot air the shelves are perforated.

\section{Moist Heat Sterilization:}

Autoclave It is an apparatus in which saturated steam under pressure effects sterilization (autoclaving). The pressure increases the boiling point of water, thereby increasing the temperature to which water can be heated. Cells are destroyed by the higher temperature and not by the pressure. Most of the organisms are killed at $121 \square$ C(i.e. $15 \mathrm{lbs} / \mathrm{in}^{2}$ ) in 15 minutes. Sterilization is done with saturated steam under pressure. Saturated steam is the water vapour at the temperature at which it is produced. Tremendous amounts of heat energy are transferred from the steam to the object when saturated steam condenses on the surface of the cooler objects. Saturated steam heats an object about 2500 times more efficiently than does hot air at the same temperature Autoclave is the most efficient and common instrument used for sterilizing solid and liquid media for microbial cultures, heat stable liquids-usually the common media ingredients, heat resistant instruments and equipments, glassware and rubber products. Scalpels and other sharp metal instruments are damaged by constant flaming and 
are usually sterilized by autoclaving. Autoclaving is not recommended for oils, powders, heat sensitive fluids and plastics (that melt).

An autoclave is a double-walled cylindrical metallic vessel, made of thick stainless steel or copper, one end of which is open to receive the material to be sterilized. Autoclave lid is provided with pressure gauge for noting the pressure, steam cock (exhaust valve) for air exhaustion of the chamber. Autoclave is provided with controls for adjusting the pressure and temperature and safety valve to avoid explosions. The articles to be sterilized are kept loosely in a basket, provided with holes all around for the free circulation of the steam. To increase the area for the materials to be sterilized, metallic separators, having holes can be use 